\title{
Utilization of Kelut's Volcanic Ash as the Aggregate Mixture of Concrete Brick
}

By Siti Salamah 


\title{
Utilization of Kelut's Volcanic Ash as the Aggregate Mixture of Concrete Brick
}

\author{
Siti Salamah ${ }^{1, a,{ }^{*}}$ and $10^{2}$ ryudi ${ }^{1, b}$ \\ ${ }^{1}$ Chemical Engineering Study Program, Universitas Ahmad Dahlan \\ Kampus III, JI. Prof. Soepomo, Janturan Yogyakarta Indonesia \\ asitisalamah@che.uad.ac.id, 'bmaryudi@che.uad.ac.id \\ ${ }^{*}+62-274563515-$ ext.3131
}

Keywords: Kelut's volcanic ash; concrete brick; mechanical characteristics.

\section{1}

Abstract. Kelut volcano had erupted in February 2014. The eruption has produced various materials i.e. ash, sands, etc. Volcanic ash contains various elements such as $\mathrm{Si}, \mathrm{Al}, \mathrm{Ca}, \mathrm{Fe}, \mathrm{Na}$ and $\mathrm{P}$. It is 11 tential to be used as raw material for cement-based products. This study investigates the utilization of Kelut's volcanic ash as the raw material of cement-brick. The Kelut's volcanic ash was analyzed to determine the contents of iron $(\mathrm{Fe})$, aluminum $(\mathrm{Al})$, and silica $(\mathrm{Si})$. The volcanic ash was screened to obtain 100 mesh size of ash. The volcanic ash of 100 mesh size was mixed with cement, sand, and water with ratio of $1 \mathrm{~kg}$ cement, $2 \mathrm{~kg}$ volcanic ash, and $15 \mathrm{~kg}$ sand $(1: 2: 15)$. The mixture of volcanic ash, sand and cement was poured and pressed in the concrete brick mold. The concrete brick was then aerated in a room for hardening process. The experiment was repeated for another ratio of raw material (cement: volcanic ash: sand $=2: 1: 15$ ) and the age of the concrete brick $(46,61,75$ and 89 days). Concrete bricks were analyzed to determine the quality and the mechanical characteristics. The results has shown that Kelut's volcanic ash has a composition of aluminum (Al) $4.707 \%$, silica $\left(\mathrm{SiO}_{2}\right) 23.4 \%$, and iron $(\mathrm{Fe}) 3.85 \%$, that is like the composition of the cement materials. The concrete bricks which are made of cement, Kelut's volcanic ash, and sand with the ratio of 21:15 has a maximum compression strength of 18.85 $\mathrm{MPa}$ at the age of 89 days. The addition of Kelut's volcanic ash has improved the strength of concrete brick. However, too much volcanic ash will lead to increasing compression strength.

\section{Introduction}

Mount Kelut is one of volcanoes in Indonesia. Kelut volcano $(1731 \mathrm{~m})$ is a strato-volcano located in East Java between the towns of Kediri, Blitar, and Malang. It is one of the most lethal volcanoes in Indonesia, with more than 15.000 people killed by its historic eruptions [1]. Kelut volcano erupted on midnight of February 13, 2014. Eruption column reached $17 \mathrm{~km}$ height and produced tephra-fall deposit up to $5002 \mathrm{n}$ away. The estimated volume of eruption was $\pm 0.78 \mathrm{~km}^{3}$ [2]. These deposits wer 6 haracterized by dense lava dome block of various sizes mixed in a matrix of lapilli and ash [1]. Volcanic ash may stay in the environment for months or years following an eruption and can affect people of hundreds of kilometers away from the volcano [3]. Several studies on Kelut's eruption have been done. Bélizal et al. [1] have studied the phenomenology, crisis management and social response of Kelut's eruption. Wibowo et al. [2] studied about distribution area, thickness, grain size, volume, and petrologic characteristics of tephra fall deposit. Previously, Mount Merapi in Middle Java- Yogyakarta area erupted in 2010. Study on Merapi volcanic ash has been conducted by Wahyuni [4] who have investigated the chemical composition of Merapi's volcanic ash. The result showed that Merapi's volcanic ash was composed of various elements such as $\mathrm{SiO}_{2}, \mathrm{Ti}, \mathrm{Al}, \mathrm{Fe}, \mathrm{Mn}, \mathrm{Ca}, \mathrm{Na}, \mathrm{Cr}$ and phosphorus as $\left(\mathrm{P}_{2} \mathrm{O}_{5}\right)$. The study have revealed that Merapi's volcanic ash contains a lot of silica, which can be used as main materials for cement manufacture or aggregate of concrete [4]. Kelut's volcanic ash may have a similar content with that of other volcanoes, e.g. Merapi's volcanic ash. Salamah [5] also studied the characterization of Merapi's volcanic ash and its utilization as batik dye adsorbent. The results showed that Merapi's 
14 canic ash contains heavy metal elements such as $\mathrm{As}, \mathrm{Pb}, \mathrm{Cr}$, and $\mathrm{Cu}$, and metal elements such as aluminum $(\mathrm{Al})$, calcium $(\mathrm{Ca})$, iron $(\mathrm{Fe})$, manganese $(\mathrm{Mn})$, and sodium $(\mathrm{Na})$. The capability of Merapi's volcanic ash as adsorbent for batik industrial waste has been studied previously [6]. The results revealed that the Merapi's volcanic ash adsorbent has a lower capability compared to other adsorbents i.e. natural zeolite. Gunawan [7] explains that Kelut's volcanic ash can be used as a good construction material mixture because it can generates strength up to $150 \mathrm{~kg}$ load unit. Volcanic ash is formed from magma ejected explosively as grains of ash. Kelut's volcanic ash that was ejected on February 14, 2014 was a taper-shaped. Commonly, the largest content of volcanic ash is silica. This research was aimed to investigate the capability of volcanic ash from Mount Kelut as materials or aggregate for the manufacture of concrete brick. It was expected to provide alternative utilization of volcanic ash if there was an eruption of volcano.

\section{Materials and Methods}

\section{Materials}

Materials are sand, cement, water, and Kelut's volcanic ash. Volcanic ash was taken from eruption of Mount Kelut on February 14, 2014. It was collected in the area of Sinduadi, Mlati, Sleman, Yogyakarta, Indonesia (about $180 \mathrm{~km}$ away from Mount Kelut).

\section{Methods}

1. Surface area and mineral contents of volcanic ash analysis

Kelut's volcanic ash was sieved with a size of 100 mesh and put into oven at temperature of $100{ }^{\circ} \mathrm{C}$ for 1 hour. The sample was analyzed for its surface area and mineral contents of aluminum ( $\mathrm{Al})$, iron $(\mathrm{Fe})$ and silica $(\mathrm{Si})$ using Atomic Absorption Spectrophotometry (AAS).

2. Concrete brick fabrication and test

Each ingredient (i.e. cement, sand, Kelut's volcanic ash) is weighed with a ratio of the cement: volcanic ash: sand $=3.0: 0: 15$ (3.0 parts: 0 parts: 15 parts) as concrete brick without Kelut's volcanic ash. The concrete brick with no volcanic ash is referred as no-ash concrete brick and used as a control or standard concrete brick. All ingredients were mixed with enough water until it was considered as homogeneous mixture. The mixture was poured into the concrete brick mold and pressed. The dimension of the mold (length $\mathrm{x}$ wide $\mathrm{x}$ height) was $100 \mathrm{x} 97 \mathrm{x} 90 \mathrm{~mm}$. Following the molding process, the concrete brick was left to stand for approximately one day, until it was dry or strong enough to be moved. Those steps were repeated for the ratio of cement: volcanic ash: sand = 1: $2: 15$ parts and the ratio of cement: volcanic ash: sand $=2: 1: 15$. Five concrete bricks were taken for density test and another 5 concrete bricks for mechanical (compressive) testing at every curing time of $28,47,61,75$, and 89 days. The average values were reported. The standard (no-ash) concrete bricks were tested at curing time of 89 days only.

\section{Result and Discussion}

\section{Analysis surface area}

The results show that Kelut's volcanic ash has a specific surface area of $4.533 \mathrm{~m}^{2} / \mathrm{g}$, total pore volume of $4.527 \times 10^{-3} \mathrm{cc} / \mathrm{g}$ and a 1 re radius of $19.973 \AA$.

\section{Contents of mineral elements of Kelut's volcanic ash}

Kelut's volcanic ash was analyzed for its mineral content using AAS (Atomic Absorption Spectrometry). The results of the analysis are shown in 1 able 1 .

Table 1 Mineral Elements of Kelut's Volcanic Ash

\begin{tabular}{rcc}
\hline Sample & Parameter & Result [\%] \\
\hline Kelut's volcanic ash & Si (silica) & 23.400 \\
& Al (aluminum) & 4.707 \\
& Fe (iron) & 3.857 \\
\hline
\end{tabular}




\section{Concrete brick characteristics test}

Table 2 Analysis results of concrete brick density

\begin{tabular}{|c|c|c|c|c|c|}
\hline \multirow{2}{*}{ No } & \multicolumn{3}{|c|}{ Composition } & \multirow{2}{*}{$\begin{array}{l}\text { Age } \\
\text { [days] }\end{array}$} & \multirow{2}{*}{$\begin{array}{c}\text { Mean density } \\
{\left[\mathrm{kg} / \mathrm{m}^{3}\right]}\end{array}$} \\
\hline & Cement [kg] & Kelut's volcanic ash $[\mathrm{kg}]$ & Sand $[\mathrm{kg}]$ & & \\
\hline 1 & 3 & 0 & 15 & 89 & 1899.2 \\
\hline \multirow{5}{*}{2} & \multirow{5}{*}{1} & \multirow{5}{*}{2} & \multirow{5}{*}{15} & 35 & 1826.6 \\
\hline & & & & 47 & 1859.2 \\
\hline & & & & 61 & 1962.8 \\
\hline & & & & 75 & 1942.0 \\
\hline & & & & 89 & 2000.0 \\
\hline \multirow{5}{*}{3} & \multirow{5}{*}{2} & \multirow{5}{*}{1} & \multirow{5}{*}{15} & 35 & 1918.6 \\
\hline & & & & 46 & 1948.8 \\
\hline & & & & 61 & 1938.6 \\
\hline & & & & 75 & 2033.4 \\
\hline & & & & 89 & 2022.0 \\
\hline
\end{tabular}

\section{Concrete brick compressive strength test}

The quality of the concrete bricks increase with the increase of the age of the concrete brick. The results of concrete brick compressive strength test are presented in the Figure 1.

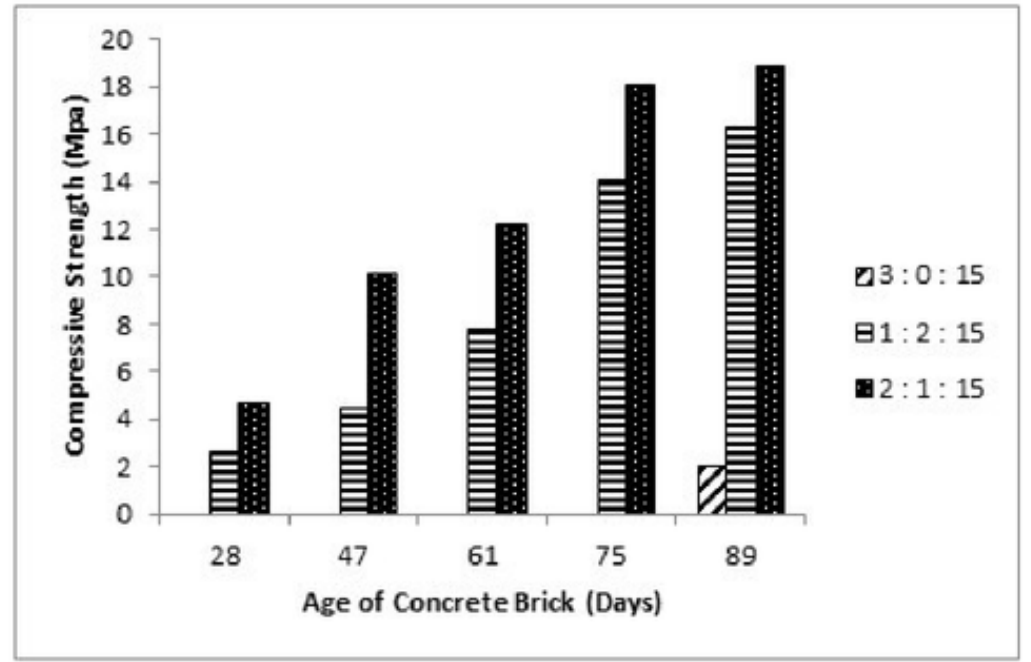

Figure 1 Compressive strength of concrete brick at various age (days)

\section{Discussion}

\section{Results of volcanic ash characterization}

The results show that Kelut's volcanic ash has a specific surface area of $4.533 \mathrm{~m}^{2} / \mathrm{g}$, total pore volume of $4.527 \times 10^{-3} \mathrm{cc} / \mathrm{g}$ and a pore radius of $19.973 \AA$. It appears that Kelut's volcanic ash is not suitable to be used as an adsorbent because its specific surface area is small, compared to other adsorbent such as zeolite which has a specific surface area of $29.366 \mathrm{~m}^{2} / \mathrm{g}$. However, Kelut's volcanic ash is more suitable to be aggregate for manufacture of concrete brick materials, due to its high content of silica $(23.400 \%)$.

The composition (silica, aluminum and iron) of silica sand in the raw material of Ordinary Portland Cement (OPC) manufacturer is $17.69 \%, 4.37 \%$, and $3.35 \%$, respectively [8-10]. Kelut's volcanic ash with $23.400 \%$ silica, $4.707 \%$ aluminum and $3.707 \%$ iron, has characteristics that meet the specification of raw material of cement or cement-based material, e.g. concrete brick. The 
quality of concrete brick is affected by the water contents of cement and the age of the concrete brick. Cement that mainly composed of silica is the most important component of concrete brick. Cement and water will undergo a reaction of hydration. The hydrate compound of cement has plasticity and ability to adhere to other materials.

\section{Concrete brick characteristics test}

Results in Table 2 show that the density characteristics of concrete bricks increase with the increase of the age of the concrete brick, compared with no-ash concrete brick. Minimum age of concrete bricks sample is 28 days since it is the minimum age limit of concrete brick to apply in building [11]. The density of no-ash concrete brick after put in oven is $1899.2 \mathrm{~kg} / \mathrm{m}^{3}$, while the density of concrete bricks with the addition of Kelut's volcanic ash which hereinafter referred as ash concrete bricks at the same age is $2022 \mathrm{~kg} / \mathrm{m}^{3}$. This is probably due to the increasing of the age of the concrete brick results in the strengthening of $\mathrm{V}$ an der Walls bond between minerals constituting the cement and minerals constituting Kelut's volcanic ash. This process leads to the smaller volume of concrete brick and the increase of density of concrete brick.

\section{Concrete brick compressive strength test}

The quality of the concrete brick increases with the increase of the age of the concrete brick [10-11]. Figure 1 reveals that the mean compressive strength generally increase with the increase of the age of concrete brick. The no-ash concrete brick of 89 days age has strength of $2.001 \mathrm{MPa}$. Noash concrete brick was tested on the compressive strength at the longe 13 ays because no volcanic ash mixed in the concrete brick and thus considered as constant. The compre11ve strength of the ash concrete brick increases with the increase of the age of the concrete brick. At the age of 89 days the compressive strength of the concrete brick is $18.89 \mathrm{MPa}$. It has exceeded the strength of a good standard concrete brick. The good standard concrete brick has compressive strength of $100 \mathrm{~kg} / \mathrm{cm}^{2}$ (9.8 MPa) (SNI 3-0349-1989) [11, 12].

Ash concrete brick has compressive strength above the average. This is probably due to the increasing of concrete brick age (curing time) resulting an increase in 12 density of the concrete brick. It leads to the hardening of the materials and thus increases the compressive strength of the concrete brick. The increase in the compressive strength is also caused by the large amount of silica content of the volcanic ash, with the increase in the age of the concrete brick the bonds between molecules are getting stronger. Volcanic ash could be considered as trash in cement manufacture. Trash is the material that is produced during the volcanic eruption. Trash is fine-grained and contains lots of amorphous silica oxide $\left(\mathrm{SiO}_{2}\right)$ that has experienced weathering up to a certain degree. It is also one of the basic ingredients of cement manufacture. Trash is used as a mixture of PPC type cement as pozolan activity. The addition of trash is intended so that the free line levels can be reduced to provide more stable compressive strength. Main content of Trash is active silica as $\mathrm{SiO}_{2}$, which with the addition water will react, with $\mathrm{Ca}(\mathrm{OH})_{2}$ to form $\mathrm{CSH}$ (calcium silica hydra 9 ) and thus contributes to the compressive strength. Chemical equation of calcium hydrate is as follows.

$$
\begin{array}{ll}
\mathrm{CaO}+\mathrm{H}_{2} \mathrm{O} & \rightarrow \mathrm{Ca}(\mathrm{OH})_{2} . \\
\mathrm{Ca}(\mathrm{OH})_{2}+\mathrm{SiO}_{2} & \rightarrow \mathrm{CaOSiO}{ }_{2} \cdot \mathrm{H}_{2} \mathrm{O} .
\end{array}
$$

The compressive strength of ash concrete brick is more stable than no-ash concrete brick because it contains many CSH particles, which are originated from the $\mathrm{SiO}_{2}$. The $\mathrm{SiO}_{2}$ content is contributed by the cement and the volcanic ash that is added to the mixture. Based on the above data, good compressive strength of the concrete brick is obtained at a ratio of cement: volcanic ash: sand $=2$ : 1: 15. It is due to the adhesive characteristic of cement and the addition of Kelut's volcanic ash, which contains $\mathrm{SiO}_{2}$, will result in the bonds between the minerals add strength to the concrete brick. 


\section{Summary}

1. Kelut's volcanic ash that contains aluminum of $4.707 \%$, silica of $23.4 \%$ and iron of $3.86 \%$ is suitable to be aggregate mixture for concrete brick.

2. Concrete brick has a maximum strength test at the ratio of cement: ash: sand $=2: 1: 15$ with strength of $18.85 \mathrm{MPa}$ at the age of 89 days.

3 . The longer the age of concrete brick, the greater compressive strength of the brick.

\section{Acknowledgement}

This project has been supported by Research and Development Institute, Universitas Ahmad Dahlan, Internal Grant No PHB-147/LPP-UAD/III/2015

\section{References}

[1] E.D. Bélizal, F.Lavigne, J.G.Galiard, D. Grancher, Geomorphology, 03643 (2011) 1-11.

[2] H.E. Wibowo, A. Harijoko, H. Humaida, A.A. Wati, M.Nakagawa, Proceedings of the Cities on Volegnoes 8. 2014 September 9-13, Yogyakarta, Indonesia (2014)

[3] J. Horwell Claire, Grain-Size analysis of volcanic ash for the rapid assessment of respiratory health hazard, J. Environ. Monit. 9 (2007) 1107-1115.

[4] E.T. Wahyuni, Determination of chemistry Composition volcanic ash from Merapi Mountain Eruption", Journal of Human and Environmental, 19 (2012) 150-159.

[5] S. Salamah, The Characterization of Merapi volcanic ash as adsorbent for batik dyes adsorbent, Report Research, Research and Development Institute, Ahmad Dahlan University, (2013)

[6] S. Salamah, The use of Merapi volcanic ash for as adsorbent dyes removal from batik waste water, Report Research, Research and Development Institute, Ahmad Dahlan University, (2014)

[7] $P_{3}$ Gunawan, Kelut's volcanic ash has big benefits", Warta Muhammadiyah, (2014)

[8] A. Mellado, C. Catalan, N. Bouzon, M.N. Borracheo, M. J. Monzo., J. Paya, Carbon footprint of geopolymer mortar : study of the contribution of the alkaline activating solution and assessment of an alternative route 8 (2014) 238

[9] W. Pahir John, Green chemistry for sustainable cement production and use, Green Chemistry, 8 (2006) 763-780

[10] I. Milicevic, D. Bjegovic, R. Siddique, Experimental research of concrete floor block with crushed bricks and tiles aggregate, Construction and Building materials, 94 (2016) 775-783

[11] B. Wintoko, Success in business of concrete brick and paving block, Pustaka Baru Press, Yogyakarta, Indonesia, (2014)

[12] SNI (National Standard of Indonesia) 3-0349-1989, Concrete brick for wall construction. 


\section{Utilization of Kelut's Volcanic Ash as the Aggregate Mixture of Concrete Brick}

ORIGINALITY REPORT

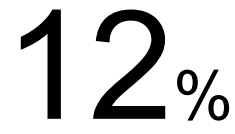

SIMILARITY INDEX

PRIMARY SOURCES

1 www.scientific.net Internet

103 words $-4 \%$

2 De Belizal, E.. "The 2007 eruption of Kelut volcano (East Java, Indonesia): Phenomenology, crisis

45 words $-2 \%$ management and social response", Geomorphology, 20120101 Crossref

3 Irfan Khan, M., Khairun Azizli, Suriati Sufian, and Zakaria Man. "Sodium silicate-free geopolymers as

30 words $-1 \%$ coating materials: Effects of $\mathrm{Na} / \mathrm{Al}$ and water/solid ratios on adhesion strength", Ceramics International, 2015.

Crossref 4 Ivanov, Roman, Valdek Mikli, Jakob Kübarsepp, and 24 words - $1 \%$
Irina Hussainova. "Direct CVD Growth of Multi-

Layered Graphene Closed Shells around Alumina Nanofibers",

Key Engineering Materials, 2016.

Crossref

5 Barsotti, S.. "Quantitative assessment of volcanic ash hazards for health and infrastructure at Mt.

23 words $-1 \%$ Etna (Italy) by numerical simulation", Journal of Volcanology and Geothermal Research, 20100420 Crossref

6 Horwell, Claire J.. "Grain-size analysis of volcanic ash for the rapid assessment of respiratory health 22 words $-1 \%$ hazard", Journal of Environmental Monitoring, 2007. Crossref

7 bib.irb.hr Internet 18 words $-1 \%$

Alexander J. Moseson. "Alkali-Activated Cement for Equitable 
Slum Improvement in Mumbai, India - A Low-CO2, Low-Cost, and Equitable Alternative", 2011 IEEE Global Humanitarian Technology Conference, $10 / 2011$

Crossref

9 Wei, Ri Guang, Shao Wei Cheng, and Jian Qiang 13 words $-<1 \%$ Gao. "The Experimental Study of $\mathrm{SO}<\mathrm{su}$ b $>2</$ sub $>$ Removal by Atomized Ammonia Injection in the Tail Flue of a 300 MW CFB Boiler", Advanced Materials Research, 2014.

Crossref

10 eprints.uad.ac.id Internet

10 words $-<1 \%$

11 Bumanis, Girts, Diana Bajare, and Aleksandrs Korjakins. "Durability of High Strength Self 9 words $-<1 \%$ Compacting Concrete with Metakaolin Containing Waste", Key Engineering Materials, 2016. Crossref

12 Singh, Navdeep Singh, S.P.. "Carbonation and electrical resistance of self compacting concrete 8 words $-<1 \%$ made with recycled concrete aggreg", Construction and Building Materials, Sept 152016 Issue Publications

13 Jo, Byung-Wan, Sumit Chakraborty, Ji Sun Choi, and Jun Ho Jo. "Investigation on the 8 words $-<1 \%$ Effectiveness of Aqueous Carbonated Lime in Producing an Alternative Cementitious Material", International Journal of Concrete Structures and Materials, 2016.

Crossref 